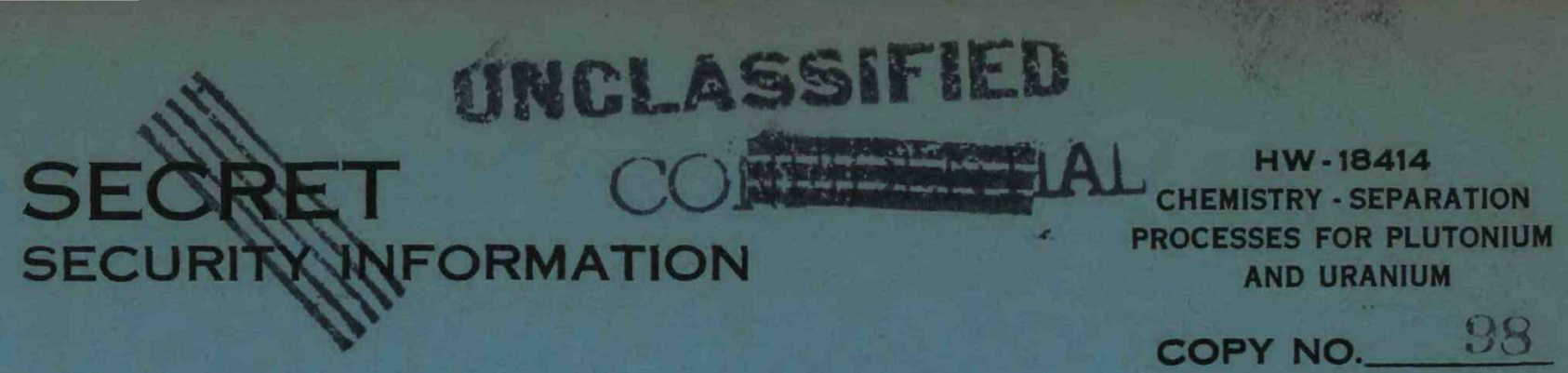

\title{
NITRIC ACID DISSOLUTION OF URANIUM-ALUMINUM ALLOY
}

BY

R. E. BURNS AND C. H. HOLM

TECHNICAL SECTION

ENGINEERING DEPARTMENT

\section{CLASSIFICATION CAMCELLED}

\section{DATE $3-28-6.0$}

For This Atomic Energy Commission

AUGUST 12,1952

-76 is

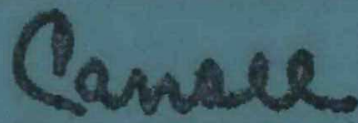

Chiet, Deciassification Branch

\section{RESTRIGLED DATA}

THIS DOCUMENT CONTAIND RESTRICTED DATA AS DEFINED IN THE ATOMIC ENIESY ACT OF 1946. ITS TRANSMITTAL OR THE DISCLS NRE OF ITS CON. TENTS IN ANY MANNER TO N WUNAUTHORIZED PERSON IS PROHIBITED.

\section{NUCLEONICS DIVISION} RICHLAND, WASHINGTON

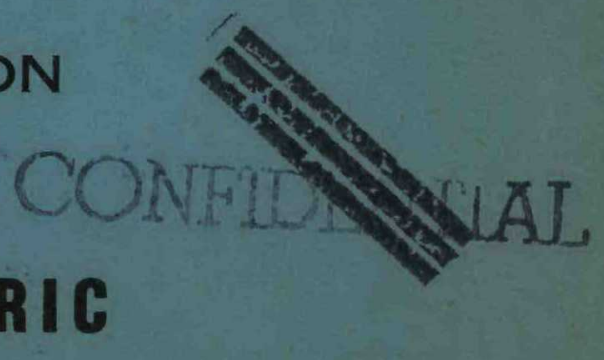

GENERAL ELECTRIC

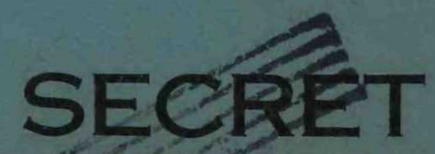

GWGLASSIFRTE

SECURITY INEORMATION

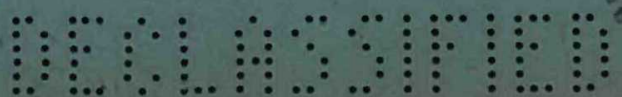




\section{DISCLAIMER}

This report was prepared as an account of work sponsored by an agency of the United States Government. Neither the United States Government nor any agency Thereof, nor any of their employees, makes any warranty, express or implied, or assumes any legal liability or responsibility for the accuracy, completeness, or usefulness of any information, apparatus, product, or process disclosed, or represents that its use would not infringe privately owned rights. Reference herein to any specific commercial product, process, or service by trade name, trademark, manufacturer, or otherwise does not necessarily constitute or imply its endorsement, recommendation, or favoring by the United States Government or any agency thereof. The views and opinions of authors expressed herein do not necessarily state or reflect those of the United States Government or any agency thereof. 


\section{DISCLAIMER}

Portions of this document may be illegible in electronic image products. Images are produced from the best available original document. 

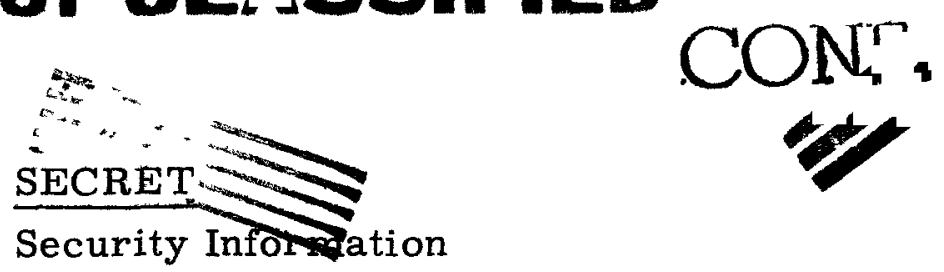

INTIAL

$\mathrm{HW}-18414$

Chemistry - Separation

Processes for Plutonium And Uranium

This document consists of 19 pages. Copy No. $\frac{98}{A}$

\section{NITRIC ACID DISSOLUTION OF URANIUM-ALUMINUM ALLOY}

By

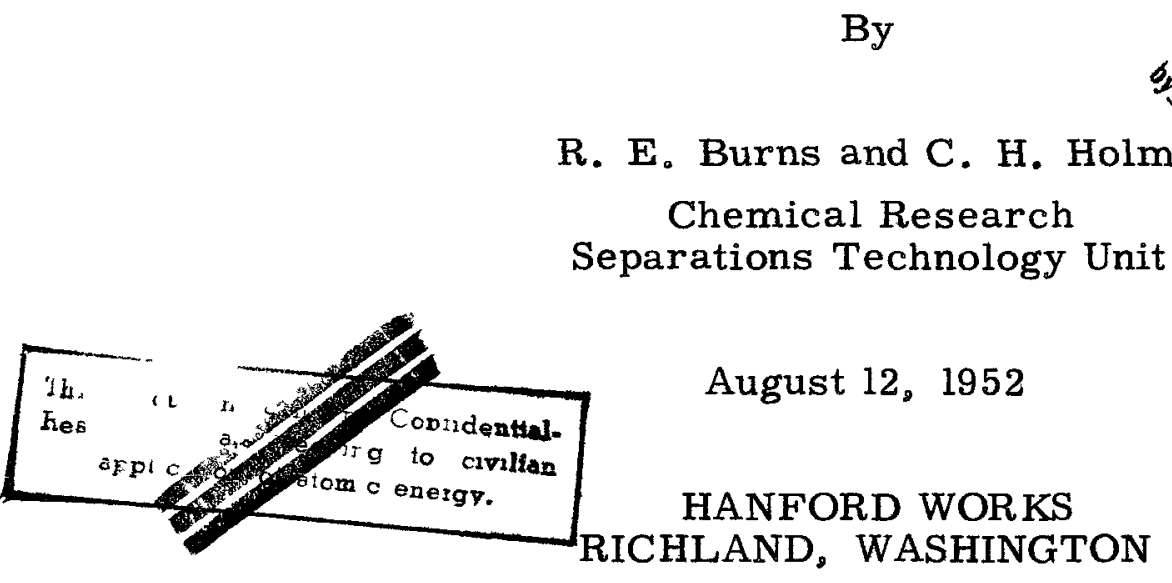

Operated for the Atomic Energy Commission by the General Electric Company under Contract \# W-31-109-Eng-52

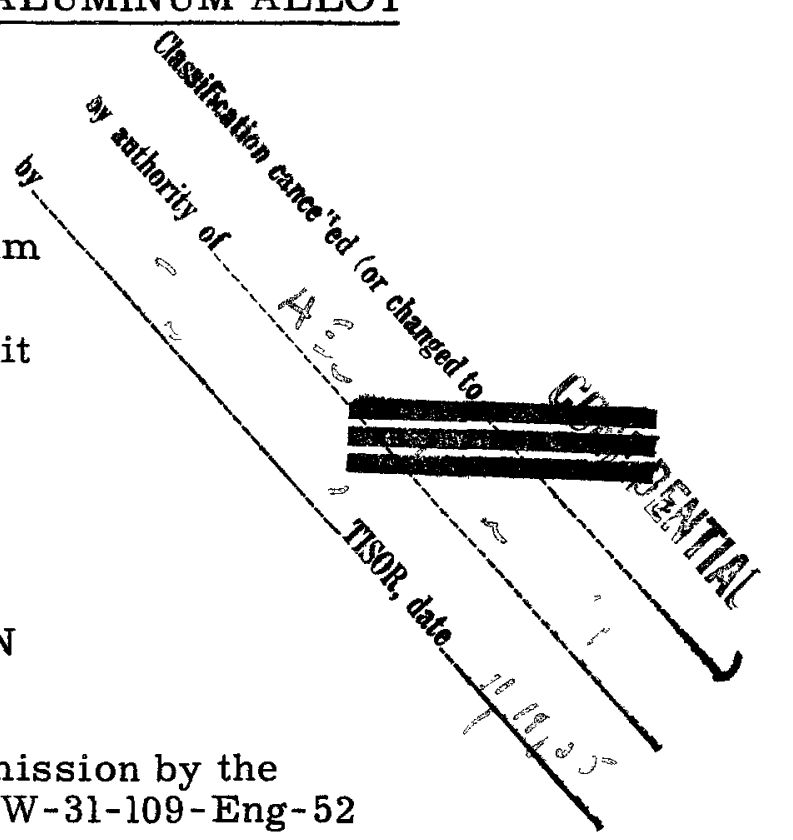

\section{RESTR NED DATA}

This document contains Restricte ta as defined in the Atomic Energy Act of 1946. Its transmitta. the disclosure of its contents in any manner to an unauthorize rson is prohibited.

\begin{tabular}{l|l|l||l|l|l}
\hline Route To & Read By & Date & Route To & Read By & Date \\
\hline & & & & & \\
\hline & & & & & \\
\hline & & & & & \\
\hline
\end{tabular}

"SEEREET 
Chemistry - Separation Processes for Plutonium And Uranium

COPY NUMBER

1

2

3

4

5

6

7

8

9

10

11

12

13

14

15

16

17

18
INTERNAL DISTRIBUTION

A. B. Greninger

O. H. Greager - W. K. Woods

R. H. Beaton

W. K. MacCready

R. B. Richards

F. W. Woodfield

O. F. Hill

V. R. Cooper

F. W. Albaugh

F. J. Leitz

J. W. Underwood

D. W. Pearce

G. W. Watt - University of Texas

R. E. Burns

C. H. Holm

300 File

700 File

Yellow Copy 


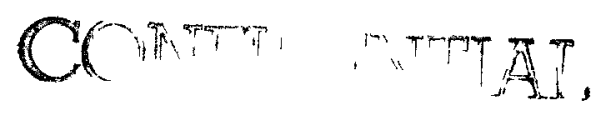

$\mathrm{HW}-18414$

Chemistry - Separation

Processes for Plutonium And Uranium

COPY NUMBER

$19-26$
27
28
$29-35$
$36-38$
$39-40$
41
$42-43$
$44-55$
$56-57$
58
$59-64$
65
$66-69$
70
$71-74$
$75-77$
78
$79-81$
82
$83-86$
$87-88$
89
90
91
$92-95$
$96-97$
$98-112$

EXTERNAL DISTRIBUTION

Argonne National Laboratory

Armed Forces Special Weapons Project (Sandia)

Armed Forces Special Weapons Project (Washington)

Atomic Energy Commission, Washington

Brookhaven National Laboratory

California Research and Development Company

Carbide and Carbon Chemicals Company (C-31 Plant)

Carbide and Carbon Chemicals Company (K-25 Plant)

Carbide and Carbon Chemicals Company (ORNL)

Carbide and Carbon Chemicals Company (Y-12 Area)

Chicago Patent Group

duPont Company

Hanford Operations Office

Idaho Operations Office

Iowa State College

Knolls Atomic Power Laboratory

Los Alamos

Massachusetts Institute of Technology (Benedict)

Mound Laboratory

Naval Research Laboratory

New York Operations Office

North American Aviation, Inc.

Patent Branch, Washington

Savannah River Operations Office (Augusta)

Savannah River Operations Office (Wilmington)

University of California Radiation Laboratory

Vitro Corporation of America

Technical Information Service, Oak Ridge

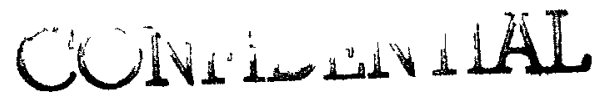




\section{ABSTRACT}

Mercury-catalyzed $\mathrm{HNO}_{3}$ dissolution of uranium-aluminum alloys was studied in an attempt to find the optimum conditions to effect dissolution in minimum time. It was found that, for any given concentration of $\mathrm{Al}\left(\mathrm{NO}_{3}\right)_{3}$ in the solution, there exists a corresponding concentration of $\mathrm{HNO}_{3}$ for which the dissolving rate is a maximum. Curves are presented showing the variation of dissolving rate with $\mathrm{HNO}_{3}$ concentration at given $\mathrm{Al}\left(\mathrm{NO}_{3}\right)_{3}$ concentrations. Calculations based on performing the dissolving in a manner such that maximum dissolving rate conditions always exist indicate a minimum dissolving time of about seven hours for U-Al cylinders $13 / 8$ inches in diameter and eight inches in length when the final solution so produced is 1. 5 M in $\mathrm{Al}\left(\mathrm{NO}_{3}\right)_{3}$.

Experiments with a continuous column-type dissolver showed that, while chemically feasible, practical application of the process would require solution of many problems such as excessive foaming, apparent preferential dissolution of aluminum, continuous feed of alloy elements to the column and plugging at the bottom of the column by small pieces of undissolved metal.

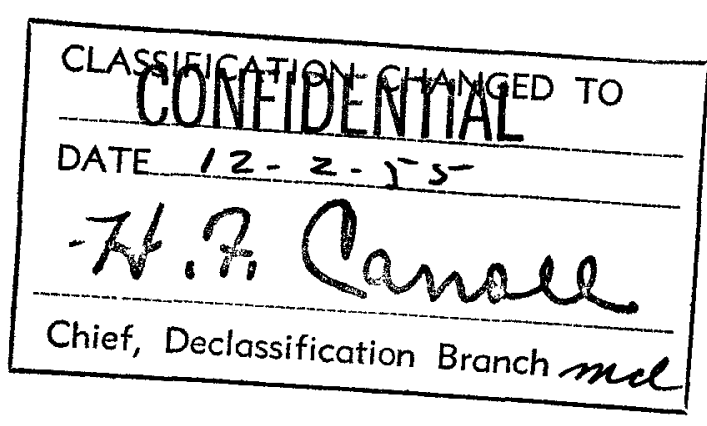




\section{CONFIDENTIAL}

$-5-$

HW-18414

\section{NITRIC ACID DISSOLUTION OF URANIUM-ALUMINUM ALLOY}

\section{INTRODUCTION}

Several pile applications now involve the use of enriched uranium in the form of uranium-aluminum (U-Al) alloy fuel elements. To recover the uranium from these fuel elements by present separation processes it is necessary that the alloy be dissolved. Since the uranium in these alloys is enriched in $\mathrm{U}^{235}$, criticality considerations require that the dissolution be performed on relatively small batches. Also, the practice, common in dissolving natural uranium fuels, of leaving a heal of undissolved metal in each batch in order to decrease dissolving time, is undesirable because of the possibility of preferential dissolving of the aluminum and consequent accumulation of $\mathrm{U}^{235}$ in the heel. It is apparent that rapid dissolution of the fuel elements is desirable to minimize the number of dissolvers required to attain a given production rate.

Dissolution of $\mathrm{U}-\mathrm{Al}$ alloys in nitric acid with $\mathrm{Hg}(\mathrm{II})$ as a catalyst has been shown to produce feeds satisfactory for solvent extraction recovery of the uranium ${ }^{(1)}$. However, dissolving times are relatively long. The studies reported here were made in an effort to establish the optimum conditions for $\mathrm{Hg}$ (II)-catalyzed nitric acid dissolution of $\mathrm{U}-\mathrm{Al}$ alloy fuel elements to obtain a minimum dissolving time. Some effort was expended in a study of a continuous dissolver of a column type with fuel elements and nitric acid entering at the top and uranium-aluminum nitrate solution leaving the bottom.

\section{SUMMARY}

All of these studies were made with U-Al alloy containing 92.5 per cent aluminum (generally $2 \mathrm{~S}$ ) and 7.5 per cent natural uranium. The alloy had been prepared in the form of cylinders $13 / 8$ inches in diameter. Results obtained confirmed expectations that the alloy would behave, during dissolution, much like aluminum alone in that the dissolving rate was markedly
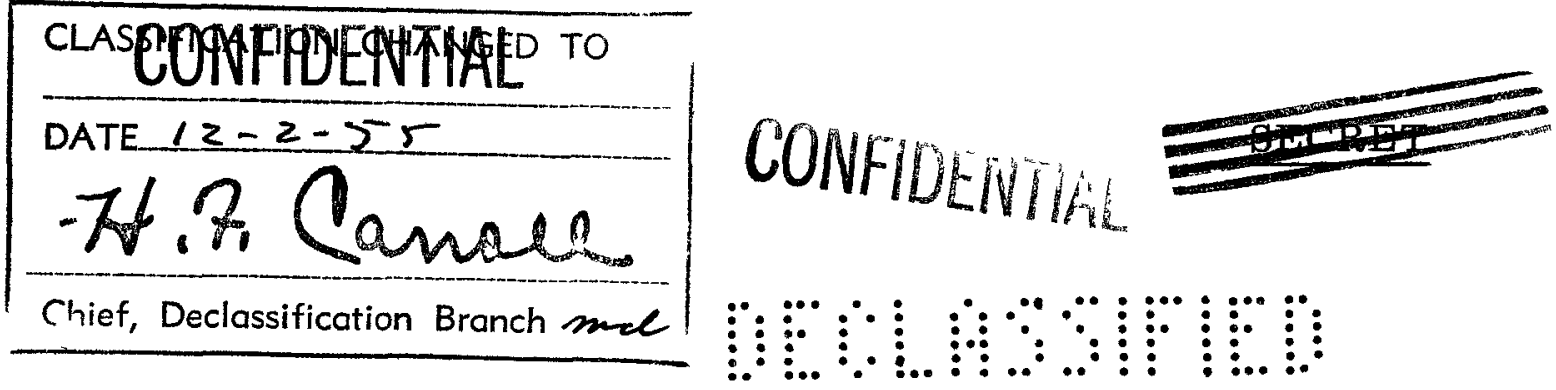
increased by increasing the temperature and by the presence of $\mathrm{Hg}$ (II) as a catalyst. It was found that there exists, for any given concentration of aluminum nitrate in the solution, a corresponding concentration of nitric acid for which the dissolving rate is a maximum. When the concentration of $\mathrm{Hg}(\mathrm{II})$ was $0.002 \mathrm{M}$, the optimum nitric acid concentrations corresponding to aluminum nitrate concentrations of $0.0,0.5,1.0$, and $1.5 \mathrm{M}$ were 4.3 , $3.3,2.3$, and 1.3 M respectively. Calculations based on performing the dissolving in a manner such that maximum dissolving rate conditions always existed indicated a minimum dissolving time of about seven hours for a U-A1 alloy fuel element $13 / 8$ inches in diameter and eight inches long when the final solution so produced was $1.5 \mathrm{M}$ in $\mathrm{Al}\left(\mathrm{NO}_{3}\right)_{3}$.

Laboratory scale experiments on a column-type continuous dissolver for $\mathrm{Hg}$ (II)-catalyzed nitric acid dissolution of $\mathrm{U}-\mathrm{Al}$ alloy fuel elements (7.5\% U-92.5\% Al; $13 / 8$ inches diameter by 8 inches long) indicate that a column five inches in diameter containing six feet of continuous liquid phase would be required to dissolve alloy equivalent to 3.5 kilograms of uranium per day. Practical application of the process would require solution of many problems such as excess foaming, apparent preferential dissolution of aluminum, continuous feed of fuel elements to the column, and plugging at the bottom of the column by small pieces of undissolved metal.

\section{EXPERIMENTAL (2)(3)}

U-Al alloy wafers cut from fuel elements $13 / 8$ inches in diameter containing 92.5 per cent aluminum and 7.5 per cent uranium were used in these studies. Dissolving rate measurements were made by immersing the wafers for short time intervals in solutions, usually at the boiling point, containing nitric acid and aluminum nitrate. From weight change and dimensional measurements, dissolving rates were calculated in terms of weight per unit area per unit time. No corrections were made for changes in solution composition due to evaporation and to dissolution of the alloy during the immersion period, or for changes in surface area of 
the wafers due to pitting during dissolution. When more than one rate determination was made on a particular wafer, it was water washed and acetone dried between measurements. Aluminum nitrate determinations on the solutions involved were made by the acidometric method. (4)

\section{A. Rate of U-Al Dissolution as a Function of Temperature}

To determine the effect of temperature on the dissolving rate of U-Al alloy in nitric acid, with and without $\mathrm{Hg}$ (II) catalyst, wafers of the alloy (1 3/8 inches in diameter and 1/4 inch thick) were immersed in the dissolvents at various temperatures for short periods of time. Weight loss and dimension measurements permitted dissolution rate calculation. The $\mathrm{Hg}(\mathrm{II})$-catalyzed dissolvent contained $4.5 \mathrm{M} \mathrm{HNO}_{3}$ and $5 \times 10^{-4} \underline{\mathrm{M}} \mathrm{Hg}$ (II) while the non-catalyzed dissolvent was 6.5 $\mathrm{M}^{-\mathrm{HNO}_{3}}$. When $\mathrm{Hg}$ (II) was present at temperatures above $50^{\circ} \mathrm{C}$, the heat of dissolution raised the solution temperature making exact measurement impossible. Foaming of the solutions was pronounced at the higher temperatures. Results of these experiments are tabulated in Table $I$ and shown graphically in Figure 1. As was expected, dissolution rate increases with increased temperature both with and without the Hg(II) catalyst. The presence of the catalyst increases the rate of dissolution markedly.

B. Effect of $\mathrm{HNO}_{3}$ and $\mathrm{Al}\left(\mathrm{NO}_{3}\right)_{3}$ Concentration on the Rate of Hg(II)-Catalyzed Dissolution of U-AI Alloy

A series of experiments was performed to determine the effect of $\mathrm{HNO}_{3}$ concentration on the rate of $\mathrm{Hg}(\mathrm{II})$-catalyzed nitric acid dissolution of $\mathrm{U}-\mathrm{Al}$ alloy at different $\mathrm{Al}\left(\mathrm{NO}_{3}\right)_{3}$ concentrations. Alloy wafers ( $1 / 2$ inch thick and $13 / 8$ inches in diameter) were immersed for short intervals in boiling solutions containing $0.002 \underline{\mathrm{M}} \mathrm{Hg}(\mathrm{II})$ and varying $\mathrm{HNO}_{3}$ and $\mathrm{Al}\left(\mathrm{NO}_{3}\right)_{3}$ concentrations. Weight change and dimensional measurements permitted calculation of dissolution rate as mentioned previously. Earlier observations of the dissolution of U-Al alloy in nitric acid containing $\mathrm{Hg}(\mathrm{II})$ indicated that ionic mercury is reduced to 
FIGURE 1

DISSOLUTION OF U-Al ALLOY

AS A FUNCTION OF TEMPERATURE

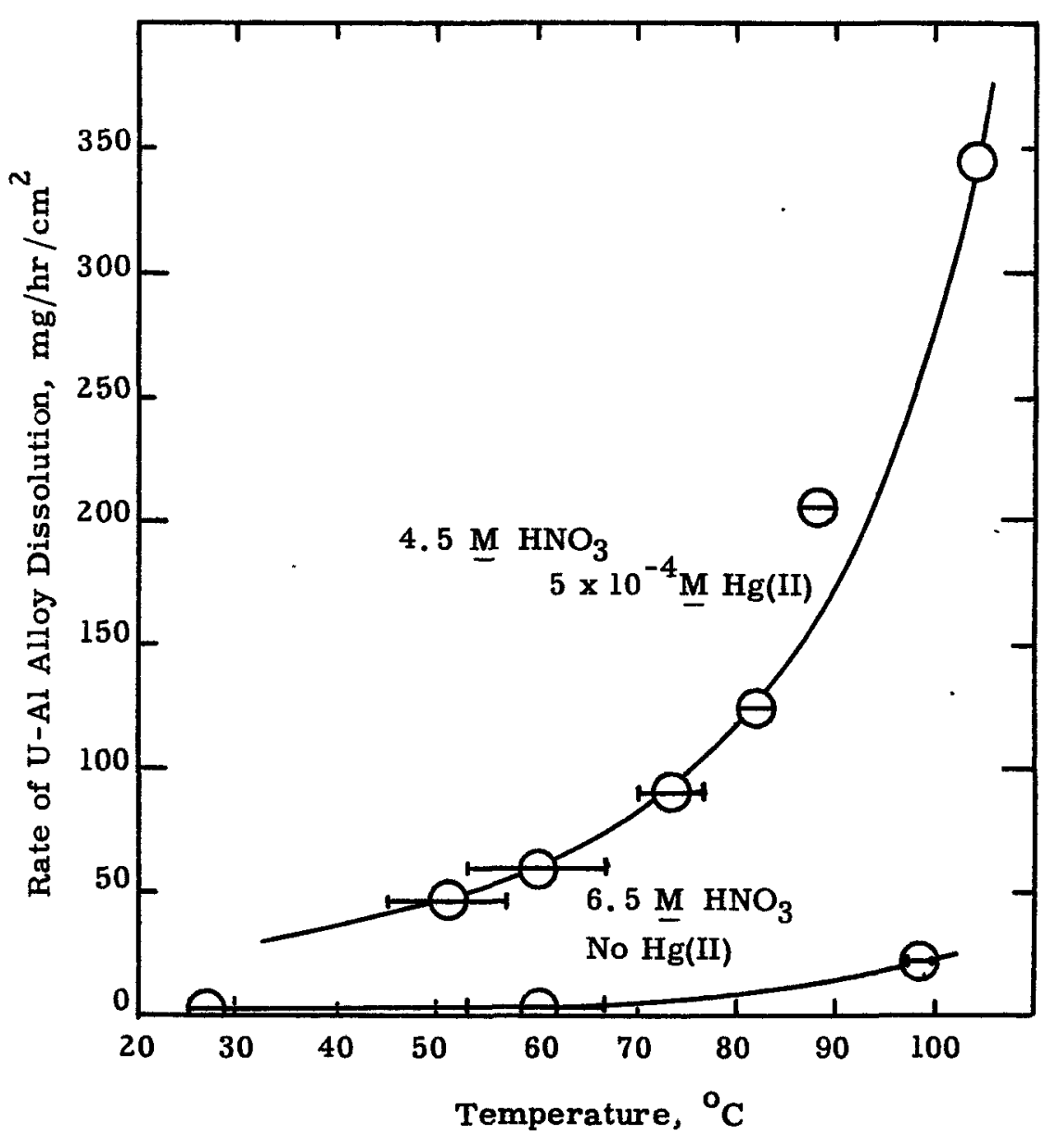


metallic mercury and deposits on the surface of the undissolved metal. It had also been observed that dissolution rates increase as the mercury deposit forms. In an attempt to avoid the varying dissolving rate which occurs while the deposit is being formed, all of the wafers used in these studies were pre-coated with mercury by immersion for a short time in $6.0 \underline{\mathrm{M}}$ nitric acid containing $0.002 \underline{\mathrm{M}} \mathrm{Hg}\left(\mathrm{NO}_{3}\right)_{2}$ 。

\section{TABLE I}

EFFECT OF TEMPERATURE

ON NITRIC ACID DISSOLUTION OF U-AI ALLOY

\begin{tabular}{ccc} 
& \multicolumn{2}{c}{ Dissolution Rate $\left(\mathrm{mg} / \mathrm{hr}^{\prime} \mathrm{cm}^{2}\right)$} \\
\cline { 2 - 3 } Temperature, ${ }^{\circ} \mathrm{C}$. & $\frac{4.5 \mathrm{M} \mathrm{HNO}_{3} \mathrm{HNO}_{3}}{3}$ & $5 \times 10^{-4} \mathrm{M} \mathrm{Hg(I)}$ \\
\hline $25-29$ & 0.21 & -- \\
$45-57$ & -- & 47.3 \\
$53-67$ & 2.39 & 59.3 \\
$70-77$ & -- & 91.1 \\
$80-84$ & -- & 124.0 \\
$86-90$ & -- & 204.8 \\
$97-100$ & 21.80 & -- \\
104 & -- & 344
\end{tabular}

When a particular wafer was used for more than one rate determination, no additional pre-coat was made between measurements. Because data obtained in these experiments tended to spread badly, in general, several rate determinations were made at any given $\mathrm{HNO}_{3}$ and $\mathrm{Al}\left(\mathrm{NO}_{3}\right)_{3}$ concentrations. Results of these experiments are summarized in Table II wherein the rates given are the average for the several determinations made at each $\mathrm{HNO}_{3}$ and $\mathrm{Al}\left(\mathrm{NO}_{3}\right)_{3}$ concentration. Spreading of the data may have been due to change in area of the wafers during immersion due to surface pitting, non-uniformity of the mercury pre-coat, gas formation on the U-Al 
TABLE II

RATE OF U-AL ALLOY DISSOLUTION AS A FUNCTION OF Al $\left(\mathrm{NO}_{3}\right)_{3}$ AND $\mathrm{HNO}_{3}$ CONCENTRATION

$2 \times 10^{-3} \mathrm{M} \mathrm{Hg}\left(\mathrm{NO}_{3}\right)_{2}$ present-in all solutions.

All solutions at boiling point.

\begin{tabular}{|c|c|}
\hline $\mathrm{ANN}, \underline{\mathrm{M}}$ & $\mathrm{HNO}_{3}$ \\
\hline 0.0 & 0.0 \\
\hline 0.0 & 2.0 \\
\hline 0.0 & 3.0 \\
\hline 0.0 & 3.5 \\
\hline 0.0 & 4.0 \\
\hline 0.0 & 4.5 \\
\hline 0.0 & 5.0 \\
\hline 0.0 & 5.5 \\
\hline 0.0 & 6.0 \\
\hline 0.0 & 7.0 \\
\hline 0.0 & 8.0 \\
\hline 0.0 & 9.0 \\
\hline 0.5 & 2.0 \\
\hline 0.5 & 2.5 \\
\hline 0.5 & 3.0 \\
\hline 0.5 & 3.25 \\
\hline 0.5 & 3.5 \\
\hline 0.5 & 3.75 \\
\hline 0.5 & 4.0 \\
\hline 0.5 & 5.0 \\
\hline 1.0 & 0.5 \\
\hline 1.0 & 1.0 \\
\hline 1.0 & 1.5 \\
\hline 1.0 & 1.75 \\
\hline 1.0 & 2.0 \\
\hline 1.0 & 2.25 \\
\hline 1.0 & 2.5 \\
\hline 1.0 & 3.0 \\
\hline 1.0 & 4.0 \\
\hline 1.5 & 0.0 \\
\hline 1.5 & 0.25 \\
\hline 1.5 & 0.5 \\
\hline 1.5 & 0.75 \\
\hline 1.5 & 1.0 \\
\hline 1.5 & 1.25 \\
\hline 1.5 & 1.5 \\
\hline 1.5 & 2.0 \\
\hline 1.5 & 2.5 \\
\hline 1.5 & 3.0 \\
\hline 1.5 & 5.0 \\
\hline
\end{tabular}

Dissolving Rate* $\mathrm{mg} / \mathrm{cm}^{2} / \mathrm{hr}$

1383

1882

1872

1877

1990

1803

1296

1283

394

256

310

803

813

906

1139

1036

997

874

860

343

486

547

681

532

702

460

342

189

78

202

304

352

491

512

565

256

117

119

33

* Figures given are the average for several determinations

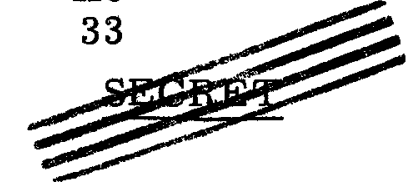


surface, and change in solution volume during dissolving. These same data are presented graphically in Figures 2 to 5.

It is apparent from Figures 2 to 5 that there appears to be an optimum $\mathrm{HNO}_{3}$ concentration, for any given $\mathrm{Al}\left(\mathrm{NO}_{3}\right)_{3}$ concentration, which will produce the most rapid dissolution rate, these $\mathrm{HNO}_{3}$ concentrations being $4.3,3.3,2.3$, and 1.3 for $\mathrm{Al}\left(\mathrm{NO}_{3}\right)_{3}$ concentrations of $0.0,0.5,1.0$, and 1.5, respectively. These curves are all shown on a single graph in Figure 6 with a line drawn through the points of maximum dissolution rate. Presumably one would achieve maximum dissolution rate for a batch of $\mathrm{U}-\mathrm{Al}$ alloy fuel elements if the $\mathrm{HNO}_{3}$ concentration was made to vary as indicated by that curve as the $\mathrm{Al}\left(\mathrm{NO}_{3}\right)_{3}$ concentration in the solution increased from 0 to 1.5 M.

It is of interest to note that pre-coating the $\mathrm{U}-\mathrm{Al}$ alloy with mercury as indicated previously leads to an initial dissolving rate in 9-13 $\underline{\mathrm{M}} \mathrm{HNO}_{3}$ at $0.0 \mathrm{M} \mathrm{Al}\left(\mathrm{NO}_{3}\right)_{3}$ substantially greater than when the alloy is not precoated. As dissolution proceeds, the rate gradually decreases suggesting that, in the presence of high $\mathrm{HNO}_{3}$ concentrations, the mercury coating is dissolved allowing the uncoated U-Al surface to exhibit the well-known passivity of aluminum to nitric acid. The lower dissolving rates at low $\mathrm{HNO}_{3}$ and high $\mathrm{Al}\left(\mathrm{NO}_{3}\right)_{3}$ concentrations is probably related to the approach to saturation with respect to $\mathrm{Al}\left(\mathrm{NO}_{3}\right)_{3}$.

Figure 7 shows the manner in which the optimum concentration of $\mathrm{HNO}_{3}$ (to give maximum dissolving rate) varies as $\mathrm{Al}\left(\mathrm{NO}_{3}\right)_{3}$ concentration varies from 0 to $1.5 \mathrm{M}$. Figure 8 shows the variation in dissolving rate as $\mathrm{Al}\left(\mathrm{NO}_{3}\right)_{3}$ concentration increases assuming that the $\mathrm{HNO}_{3}$ concentration is maintained at the proper concentration to give maximum dissolving rate. Data were obtained from Figure 8 to calculate the minimum time required to dissolve each successive one millimeter layer from a U-AI alloy fuel element $13 / 8$ inches in diameter assuming the final concentration of $\mathrm{Al}\left(\mathrm{NO}_{3}\right)_{3}$ to be $1.5 \mathrm{M}$. Summation of these times, as shown in 
RATE OF URANIUM ALUMINUM ALLOY DISSOLUTION

AS A FUNCTION OF NITRIC ACID CONCENTRATIONS

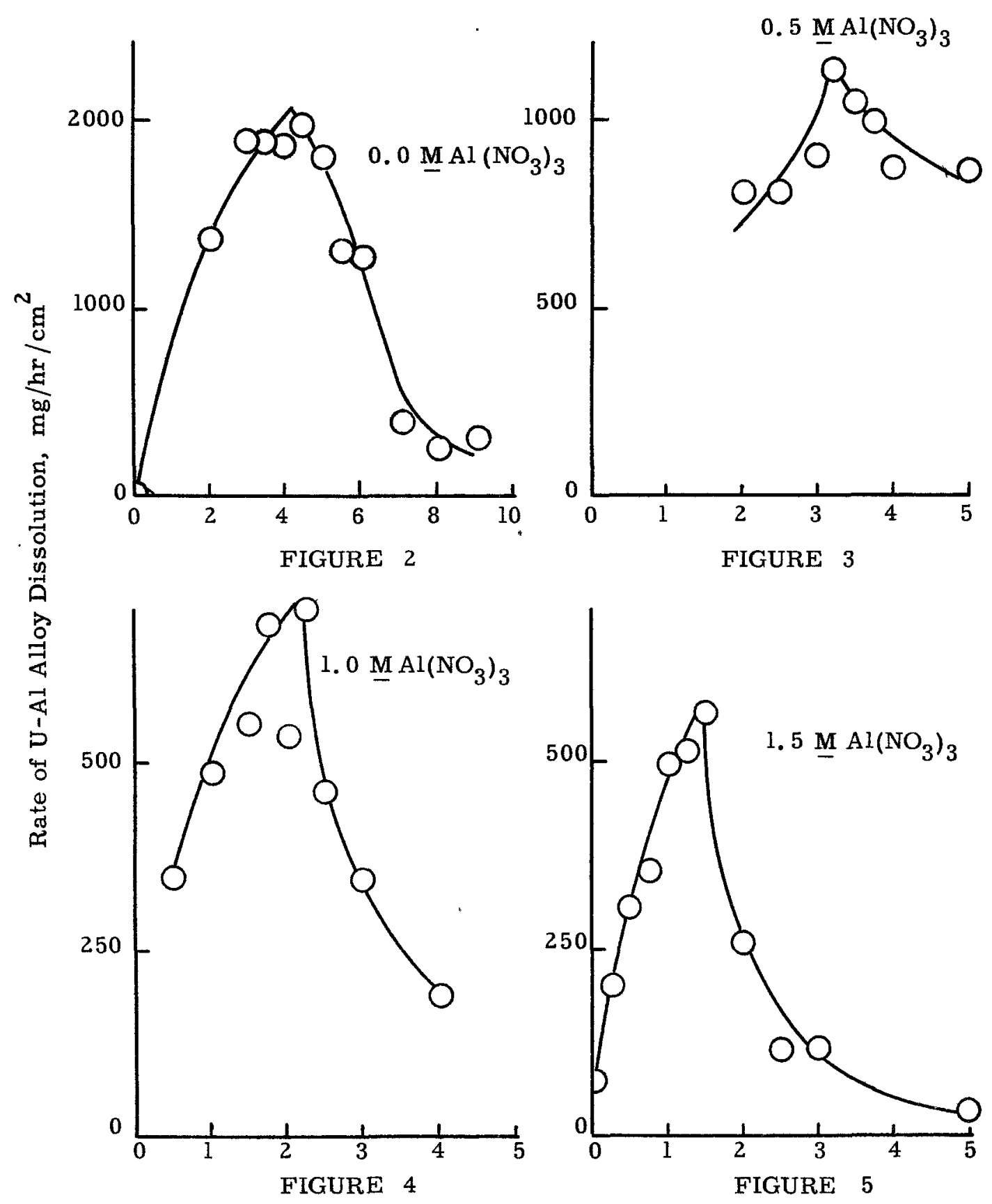

Nitric Acid Concentration, Molarity

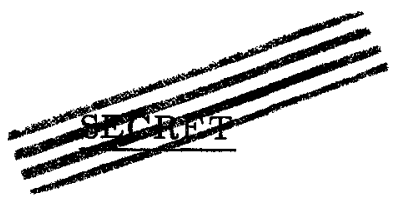




\section{FIGURE 6}

RATE OF URANIUM-ALUMINUM ALLOY DISSOLUTION AS A FUNCTION OF NITRIC ACID ALUMINUM NITRATE CONCENTRATION
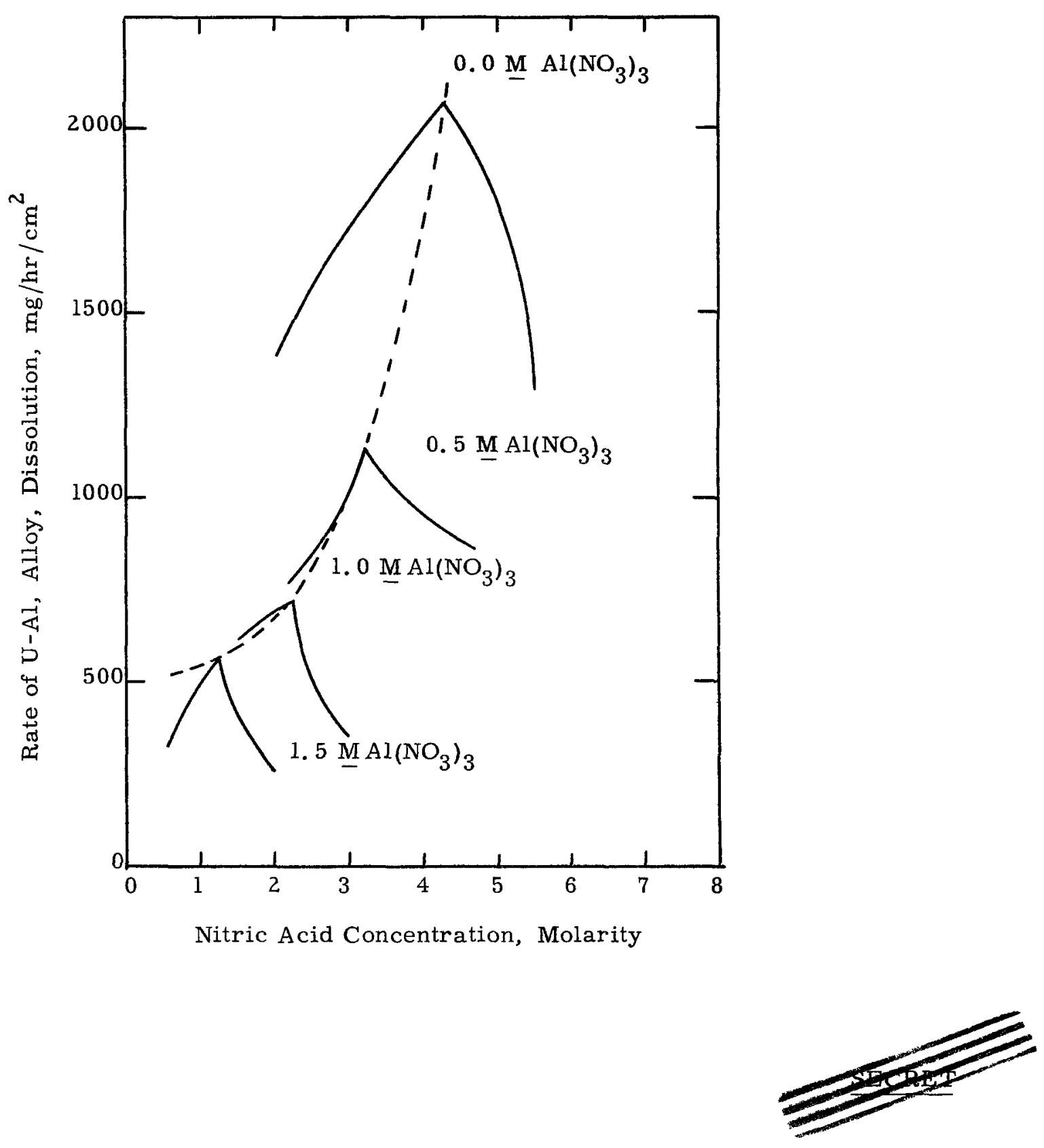


\section{F IGURE 7}

VARIATION OF $\mathrm{HNO}_{3}$ CONCENTRATION WITH Al $\left(\mathrm{NO}_{3}\right)_{2}$ CONCENTRATION TO GIVE MAXIMUM DISSOLVING RATE

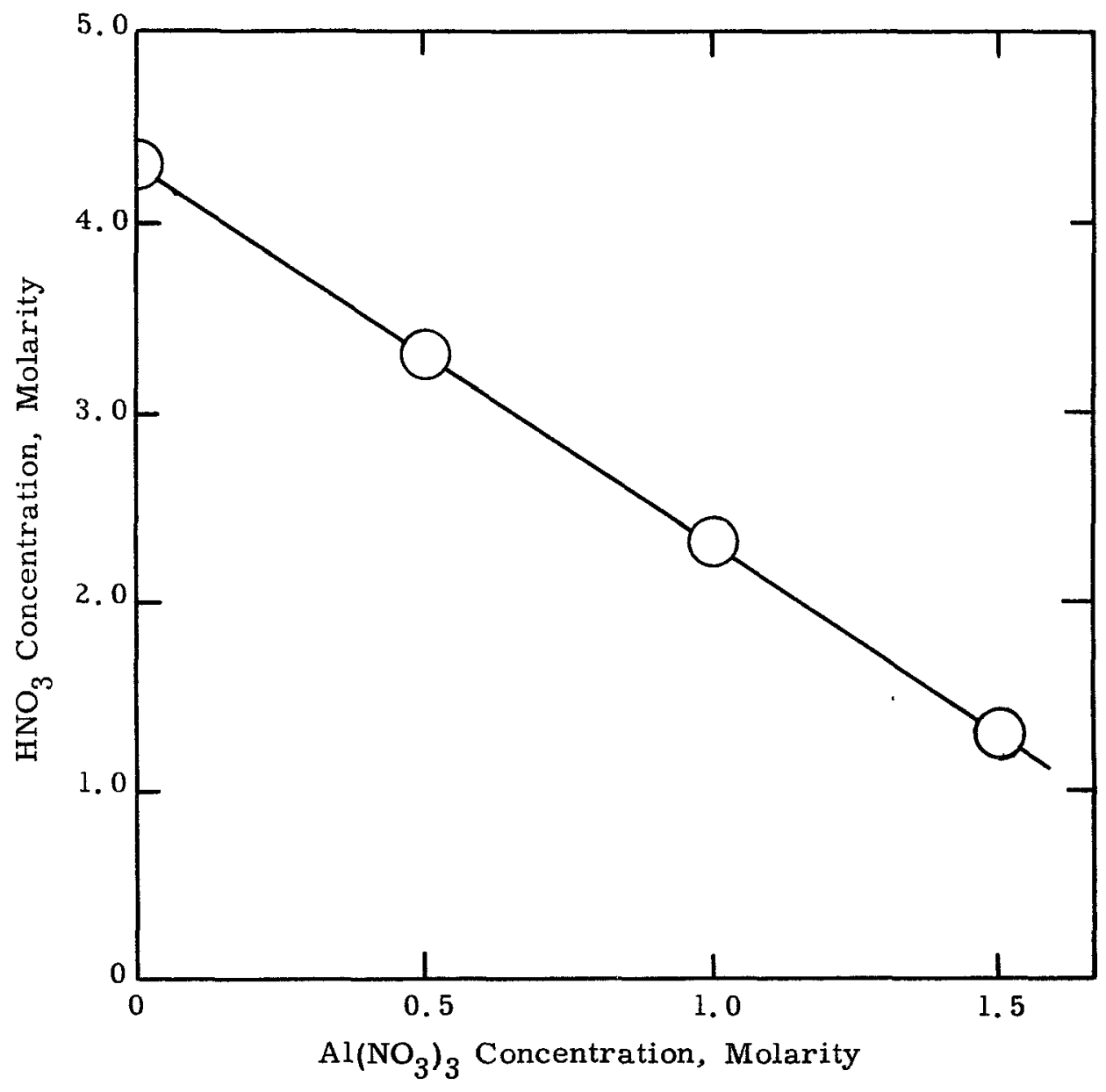




\section{FIGURE 8}

VARIATION OF MAXIMUM DISSOLVING RATE WITH CHANGING $\mathrm{Al}\left(\mathrm{NO}_{3}\right)_{3}$ CONCENTRATION

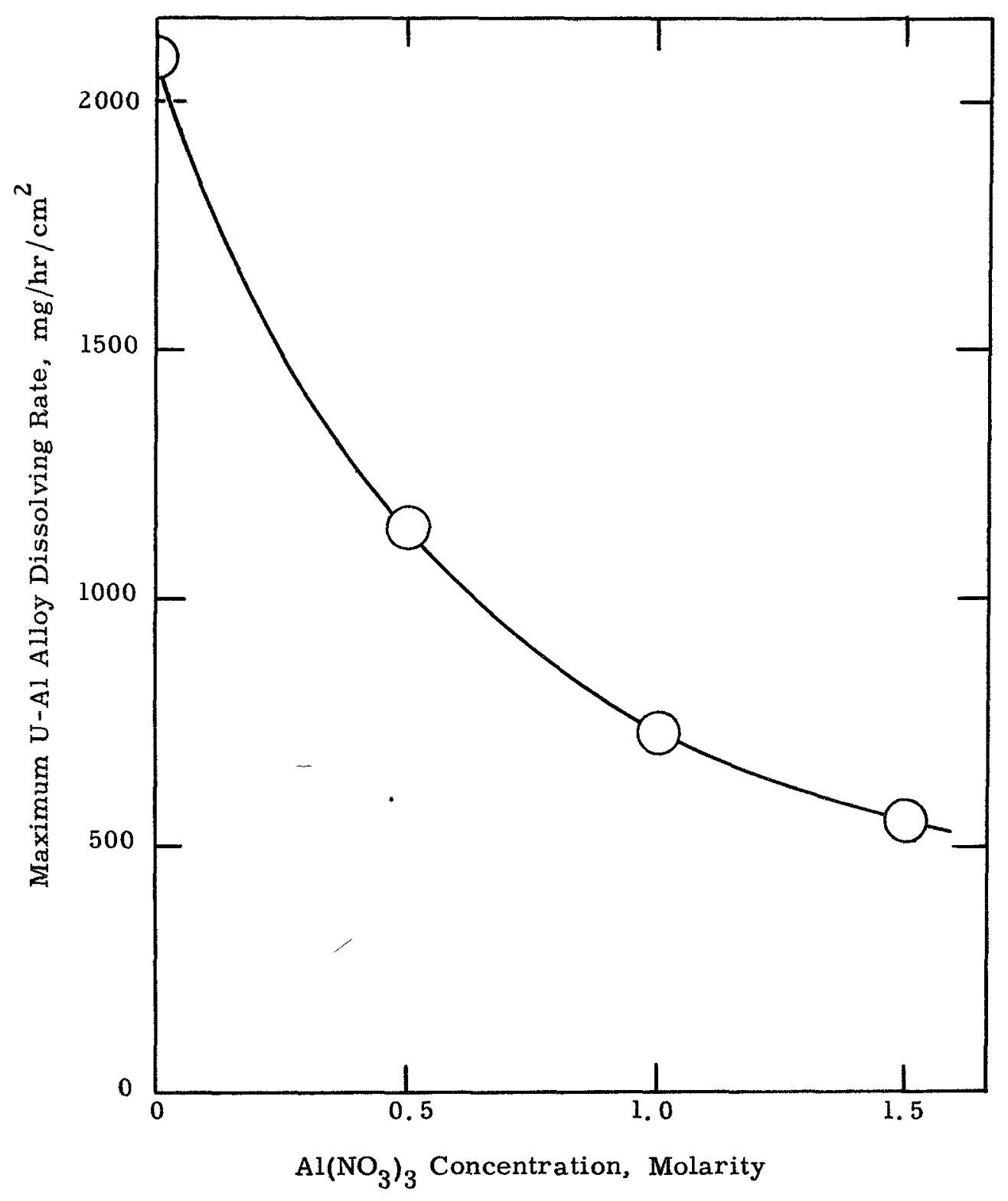


Table III, indicates a total dissolving time of about seven hours. Residual $\mathrm{HNO}_{3}$ concentration would be $1.25 \mathrm{M}$.

Examination of the data in Table III shows, also, that about 95 per cent of the slug weight would dissolve in five hours if the maximum rate curve was followed. Dissolving times of this order could be achieved if a five per cent heel could be left for the succeeding batch.

\section{Continuous Dissolution of U-Al Alloy}

As an alternative to batch dissolution of uranium-aluminum alloy some consideration was given to a continuous dissolver of the column type. The laboratory column used was two inches in diameter and 18 inches long and was provided with a heating jacket and connections to permit introduction of nitric acid at the top and withdrawal of solution from the bottom. The column was filled with $32 \mathrm{U}-\mathrm{Al}$ wafers $(7.5 \% \mathrm{U} 92.5 \% \mathrm{Al}$ $13 / 8$ inches in diameter by $1 / 2$ inch thick). Solution flow rate through the column was nine liters per hour. In practice, four liters of solution consisting initially of $6 \mathrm{MHNO}_{3}$ containing $0.002 \underline{\mathrm{M}} \mathrm{Hg}\left(\mathrm{NO}_{3}\right)_{2}$ was passed through the column and the effluent was recycled through the column in successive passes until the effluent was approximately $1.5 \mathrm{M}$ in $\mathrm{Al}\left(\mathrm{NO}_{3}\right)_{3}$. It was found impossible to maintain an 18 inch depth of liquid in the column since foaming of the solution forced it out the top of the column. The first four passes were made with only six inches of liquid in the column. As the concentration of $\mathrm{Al}\left(\mathrm{NO}_{3}\right)_{3}$ in the solution increased and the reaction rate decreased it was possible to maintain a greater liquid depth. The last three passes were made with a 12 inch liquid depth. Table IV shows, the $\mathrm{Al}\left(\mathrm{NO}_{3}\right)_{3}$ concentration in the effluent after each pass.

Estimating the two passes at $50^{\circ} \mathrm{C}$. to be equivalent to one pass at $80^{\circ} \mathrm{C}$. one may conclude from these data that about 4.5 feet of liquid phase would be required to produce an effluent $1.4 \mathrm{M}$ in $\mathrm{Al}\left(\mathrm{NO}_{3}\right)_{3}$. Since the area exposed to acid attack when wafers are employed as in these experiments is somewhat greater than if full length fuel elements ( 8 inches) were being 
TABLE III

DISSOLUTION OF ONE U-A1 SLUG FOLLOWING MAXIMUM RATE CURVE Final A NN Concentration 1.5 M

\begin{tabular}{|c|c|c|c|c|c|c|}
\hline $\begin{array}{l}\text { Penetration } \\
\mathrm{mm}\end{array}$ & $\begin{array}{l}\text { Weight } \\
\text { Loss, } \\
\text { grams }\end{array}$ & $\sum_{\substack{\text { Weight } \\
\%}}$ & $\sum_{\substack{\mathrm{A} \mathbf{N}^{-} \\
\underline{\mathbf{M}}}}$ & $\begin{array}{l}\text { A verage } \\
\text { Area } \\
\mathrm{cm}^{2}\end{array}$ & $\begin{array}{c}\text { Approximate } \\
\text { Dissolving } \\
\text { Rate } \\
\mathrm{mg} / \mathrm{hr} / \mathrm{cm}^{2}\end{array}$ & $\begin{array}{l}\text { Time, } \\
\text { Min. }\end{array}$ \\
\hline $\begin{array}{r}1 \\
2 \\
3 \\
4 \\
5 \\
6 \\
7 \\
8 \\
9 \\
10 \\
11 \\
12 \\
13 \\
14 \\
15 \\
16 \\
17 \\
18\end{array}$ & $\begin{array}{l}67.8 \\
63.2 \\
58.6 \\
54.0 \\
49.6 \\
45.2 \\
41.0 \\
36.9 \\
32.8 \\
28.9 \\
25.1 \\
21.4 \\
17.8 \\
14.4 \\
11.0 \\
7.7 \\
4.6 \\
1.5\end{array}$ & $\begin{array}{r}11.7 \\
22.5 \\
32.6 \\
41.9 \\
50.4 \\
58.2 \\
65.2 \\
71.6 \\
77.2 \\
82.2 \\
86.5 \\
90.2 \\
93.3 \\
95.7 \\
97.6 \\
99.0 \\
99.7 \\
100.0\end{array}$ & $\begin{array}{l}.18 \\
.34 \\
.49 \\
.63 \\
.76 \\
.87 \\
.98 \\
1.07 \\
1.16 \\
1.23 \\
1.30 \\
1.35 \\
1.40 \\
1.44 \\
1.47 \\
1.49 \\
1.50 \\
1.50\end{array}$ & $\begin{array}{l}251 \\
224 \\
208 \\
192 \\
176 \\
161 \\
146 \\
131 \\
117 \\
103 \\
89.6 \\
76.4 \\
63.6 \\
51.3 \\
39.2 \\
27.4 \\
16.3 \\
5.4\end{array}$ & $\begin{array}{r}1800 \\
1500 \\
1250 \\
1063 \\
937 \\
830 \\
760 \\
700 \\
660 \\
630 \\
605 \\
588 \\
575 \\
565 \\
558 \\
554 \\
552 \\
550\end{array}$ & $\begin{array}{r}9.0 \\
11.3 \\
13.5 \\
15.9 \\
18.0 \\
20.3 \\
22.2 \\
24.1 \\
25.5 \\
26.7 \\
27.7 \\
28.6 \\
29.2 \\
29.8 \\
30.2 \\
30.4 \\
30.7 \\
30.3\end{array}$ \\
\hline & & & & \multicolumn{2}{|c|}{7 hours } & 423.4 \\
\hline
\end{tabular}


dissolved one may estimate very roughly that a liquid phase depth of six feet would be required if full length elements were being dissolved.

There was visual evidence suggesting preferential dissolution of aluminum during these experiments. A finely divided dark solid remained undissolved while the solution remained in contact with undissolved alloy but subsequently dissolved when the solution was removed from contact with the alloy. Chemical composition of the dark solid was not determined.

Many other problems such as suppression of foaming, continuous loading of fuel elements to the column, and plugging at the bottom of the column by small pieces of undissolved alloy would need to be solved before continuous dissolution such as tried here could be practical.

TABLE IV

\section{CONTINUOUS DISSOLUTION OF U-AI ALLOY}

\begin{tabular}{lcccc} 
Pass & Temp. ${ }^{\circ} \mathrm{C}$. & $\begin{array}{l}\text { Liquid Phase } \\
\text { Depth, inches }\end{array}$ & $\begin{array}{c}\text { Concen. } \mathrm{Al}\left(\mathrm{NO}_{3}\right)_{3} \\
\text { in Effluent, } \mathrm{M}^{3}\end{array}$ \\
\cline { 3 - 4 } 1 & ca. 50 & 6 & 0.07 \\
3 & ca. 50 & 6 & 0.18 \\
4 & ca. 50 & 6 & 0.42 \\
5 & 80 & 6 & 0.66 \\
6 & 80 & 12 & 0.84 \\
7 & 80 & 12 & 1.09 \\
& 80 & 12 & 1.38
\end{tabular}

\section{SECPR}




\section{6..CLA=IIFIED}

SEC T

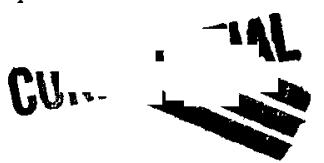

HW-18414

\section{REFERENCES}

1. Rom, A. M., Terminal Report of ORNL Pilot Plant Development of the Materials Testing Reactor 25 Recovery Process, ORNL 676, May 23, 1950.

2. Holm, C. H. , Laboratory Notebook, HW-2945-T.

3. Holm, C. H. Laboratory Notebook, HW-338-T.

4. Hayes, S. A., The Acidimetric Determination of Aluminum with Fluoride at pH 10॰11, HW-18178, June 27, 1952 .

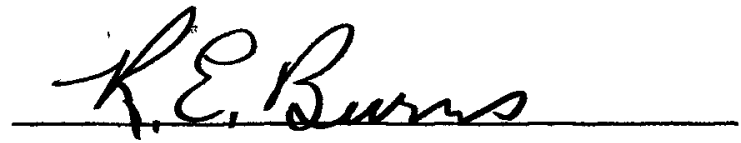

R. E. Burns

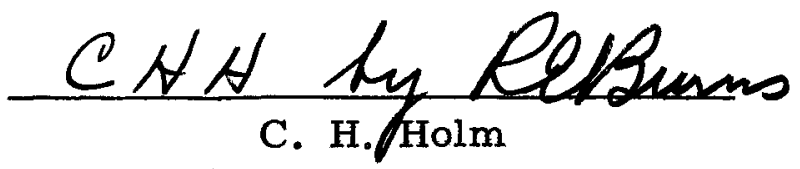

REB, CHH :dt
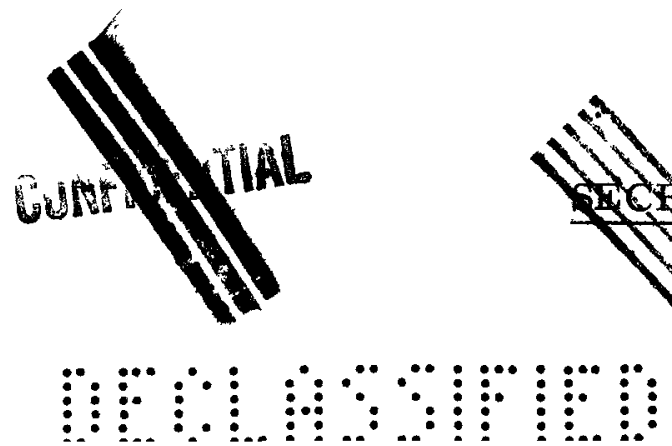